\title{
PROTOTYPE PENDETEKSI KEBOCORAN PIPA BERBASIS IOT MENGGUNAKAN NODEMCU ESP8266 MELALUI DASHBOARD ADAFRUIT.Io
}

\author{
Hendra Kusuma ${ }^{1)}$, Fachri Ramadhan ${ }^{2)}$,Ahmad Ating Alawi ${ }^{3)}$,Rifqi Nauval ${ }^{4)}$,Jodi \\ Setiawan ${ }^{5}$. \\ ${ }^{1}$ Falkutas Sains Dan Teknologi, Universitas Raharja, J1 Jendral Sudirman No 40 Modern Cikokol Tangerang \\ 15117 Banten, Indonesia (Hendra Kusuma 1) \\ email: hendra.kusumah@raharja.info \\ ${ }^{2}$ Falkutas Sains Dan Teknologi, Universitas Raharja, Jl Jendral Sudirman No 40 Modern Cikokol Tangerang \\ 15117 Banten, Indonesia (Fachri Ramadhan 2) \\ email: fachri.ramadhan@raharja.info \\ ${ }^{3}$ Falkutas Sains Dan Teknologi, Universitas Raharja, J1 Jendral Sudirman No 40 Modern Cikokol Tangerang \\ 15117 Banten, Indonesia (Ahmad Ating Alawi 3) \\ email: ahmad.ating@raharja.info \\ ${ }^{4}$ Falkutas Sains Dan Teknologi, Universitas Raharja, Jl Jendral Sudirman No 40 Modern Cikokol Tangerang \\ 15117 Banten, Indonesia (Rifqi Nauval 4) \\ email: rifqi.nauval@raharja.info \\ ${ }^{5}$ Falkutas Sains Dan Teknologi, Universitas Raharja, J1 Jendral Sudirman No 40 Modern Cikokol Tangerang \\ 15117 Banten, Indonesia (Jodi Setiawan 5) \\ email: jodi.setiawan@raharja.info
}

\begin{abstract}
ABSTRAK
Kebocoran pada pipa merupakan hal yang paling sering kita temui dalam permasalahan sehari-hari. Permasalahan ini menyebabkan kerugian secara ekonomi, baik oleh perusahaan penyedia air bersih maupun pengguna. Dalam penerapannya mendeteksi kebocoran pipa biasanya hanya menggunakan cara manual yaitu dengan hanya melihat dengan kasat mata. Penelitian ini bertujuan untuk menguji keefektifan pendeteksi kebocoran pipa yang dapat dipantau secara online. Pada penelitian ini metode yang digunakan yaitu mendeteksi aliran air yang masuk kedalam flow sensor dan tekanan yang dihasilkan dari dalam pipa yang akan dideteksi oleh sensor tekanan MPX10GP. Dari hasil tekanan dan arus yang dihasilkan akan menunjukkan seberapa besar yang dihasilkan apabila menghasilkan nilai tekanan yang tidak biasa maka ada indikasi bahwa pipa mengalami kebocoran. Data yang telah dibaca dan diperoleh dari sensor nantinya akan dikirim oleh NodeMCU ESP8266 ke dashboard adafruit.io yang bisa dipantau dari mana saja oleh pengguna ataupun teknisi.
\end{abstract}

Keywords: Pendeteksi, MPX10GP, Adafruit.Io

\section{PENDAHULUAN}

Kebocoran yang ditimbulkan pada saluran pipa merupakan permasalahan serius yang tidak dapat dianggap sebelah mata penyelesaian dan penanggulangannya. Pengguna biasanya tidak dapat mengetahui kebocoran pipa yang terjadi di rumah ataupun hal lain seperti lupa mematikan keran, yang tentunya dapat merugikan pengguna itu sendiri secara ekonomi. Seperti data yang didapat dari situs PDAM Tirta Benteng Tangerang tingkat kehilangan air berada pada angka $33 \%$ yang menandakan operasional yang masih belum efisien.
Berdasarkan data yang didapat dari Laporan yang didapat pada tahun 2017, tingkat kehilangan air di seluruh Indonesia masih menyentuh angka 32,80\% sedangkan tingkat kehilangan air PDAM yang sehat adalah $21,71 \%$ dan angka yang diharapkan yaitu berada di angka $20 \%$.

Dengan adanya penelitian ini diharapkan hal preventif[1] dapat dilakukan dengan membuat alat yang dapat mendeteksi kebocoran pipa yang dapat dipantau dari mana saja (mobile)[2] oleh pengguna atau konsumen air bersih. Pada pelaksanaan operasional, umumnya pendeteksian kebocoran pipa masih 
menggunakan cara manual yaitu melihat bagian pipa yang mengalami kebocoran dan menyusurinya. Tentunya hal ini sangat tidak efektif untuk dilakukan secara terus menerus. Seiring perkembangan teknologi hal-hal seperti ini seharusnya dapat ditanggulangi dengan baik. Pada penerapannya harapan dari penelitian ini yaitu dapat mengetahui kebocoran pipa menjadi lebih cepat, agar dapat ditangani lebih cepat pula sehingga dapat meminimalisir kehilangan air yang dapat menyebabkan kerugian dari keterlambatan penanganan serta dapat menggunakan konsep IoT sebagai wujud menerapkan kemajuan teknologi di masyarakat.

Internet of things sendiri adalah hal atau objek dalam kehidupan sehari-hari yang dapat dibaca, dikenali, diketahui lokasinya maupun ditandai dan dialamatkan melalui sensor yang dapat memberi informasi kepada mikrokontroler melalui internet maupun media wireless lainnya seperti NFC, Bluetooth, Infrared, ataupun jaringan WLAN serta dapat disimpulkan juga sebagai infrastruktur global yang dapat memberikan informasi kepada pengguna dengan berbasiskan virtual [3]

NodeMCU ESP8266 V2 merupakan mikrokontroler yang cukup populer dan dapat digunakan untuk mode wireless tanpa menggunakan modul tambahan lainnya. Pada mikrokontroler ini menggunakan tegangan yang berada pada 3,3v. Disisi lain ESP8266 ini merupakan mikrokontroler wireless yang cukup murah.[4] Selanjutnya yaitu water flow sensor adalah sensor yang dapat membaca arus yang mengalir melewatinya[5] dan dapat mengirim ke mikrokontroler untuk selanjutnya dapat ditampilkan kepada pengguna. Sensor ini menggunakan satuan analog sehingga besaran yang dihasilkan dapat dibaca dan diatur untuk dapat ditampilkan kepada pengguna. Serta sensor yang digunakan lainnya yaitu sensor tekanan MPX10GP, sensor ini dapat membaca tekanan udara yang terjadi didalam pipa[6] dengan memasukan salah selang kecil ke dalam pipa, yang nantinya sensor ini juga mengirim data ke NodeMCU ESP8266.

Berdasarkan data yang telah disajikan diatas maka ketiga komponen utama tersebut dapat dipadukan sehingga kemudian dapat membaca besar arus serta tekanan yang melewati pipa yang kemudian diberikan ke NodeMCU ESP8266 yang telah terkoneksi WiFi lalu akan dikirim ke dashboard adafruit.io dan juga mengirim notifikasi ke email, sehingga pengguna dapat melihat secara real time[7] data yang dihasilkan dari arus pipa.

\section{METODE PENELITIAN}

Salah satu metode yang digunakan oleh peneliti yaitu dengan studi literatur, berikut rujukan yang peneliti gunakan dalam penelitian ini :

1. Penelitian yang berjudul "Deteksi Letak Kebocoran Pipa Berdasarkan Analisis Debit Air Menggunakan Teknologi Sensor Flowmeter Berbasis TCP/IP" yang dilakukan oleh Duwi Hariyanto, Gurum Ahmad Pauzi dan Amir Supriyanto. Penelitian ini membahas tentang mendeteksi kebocoran pipa dengan water flow sensor yaitu dengan konsep membaca arus yang masuk pada sensor pertama dan arus yang masuk pada sensor kedua.[8]

2. Penelitian yang dilakukan oleh Muchammad Sholahuddin Al Ayub dengan judul "Perancangan Dan Penerapan Aparatus Pengukuran Debit Air Dengan Menggunakan Venturimeter Dan Water Flow Sensor" pada penelitian ini beliau membahas tentang venturimeter yang menggunakan water flow sensor untuk mengukur secara digital air yang telah mengalir.[9]

3. Paten yang dimiliki oleh James Jenkins dan William Vestal dengan judul "Water delivery system with water flow 
sensor for a refrigator" pada paten ini membahas tentang penggunaan water flow sensor untuk mengukur penggunaan air yang diperlukan refrigator.[10]

4. Penelitian yang dilakukan oleh Sasmoko D. dan Wicaksono Y.A. dengan judul penelitian "Implementasi Penerapan Internet Of Things (Iot) Pada Monitoring Infus Menggunakan Esp8266 Dan Web Untuk Berbagi Data" penelitian ini membahas tentang penggunaan ESP8266 dibidang kesehatan konsep penelitian ini adalah ESP8266 akan mengirimkan data real time secara akurat yang akan diterima oleh pengguna, databasenya menggunakan MySQL.[11]

5. Penelitian dengan judul "Prototipe Sistem Monitoring Air Pada Tangki Berbasis Internet of Things Menggunakan NodeMCU Esp8266 Dan Sensor Ultrasonik" yang dilakukan oleh Ulumuddin, M. Sudrajat, TD Rachmilda, $\mathrm{N}$ Ismail, EAZ Hamidi pada penelitian ini membahas tentang bagaimana kondisi air dalam penampungan yang harus dipantau secara terus menerus, maka digunakanlah ESP8266 sebagai Transmitter yang kemudian dipadukan dengan sensor ultrasonik.[12]

6. Penelitian yang dilakukan oleh Kodali, R. K., \& Mahesh, K. S dilakukan pada tahun 2016 dengan judul penelitian "A low cost implementation of MQTT using ESP8266" dalam penelitian ini membahas tentang komunikasi yang dilakukan ESP8266 WiFi dengan klien Smartphone dan Laptop dengan daya yang rendah dan juga biaya murah serta performa yang dapat diandalkan.[13]

7. Penelitian dengan judul "A simple method to determine leakage location in water distribution based on pressure profiles" yang dilakukan pada tahun 2016 lalu oleh Prihtiadi, H., Azwar, A., \& Djamal, M., penelitian ini mengulas tentang pembuatan pendeteksi pipa bocor menggunakan pipa sepanjang 4 meter dengan diameter $15 \mathrm{~mm}$ dan diberikan sebanyak 12 sensor pembaca tekanan, pada titik antara sensor keenam dan ketujuh dibuat lubang buatan sehingga dapat membaca tekanan yang berubah akibat lubang.[14]

8. Penelitian yang dilakukan oleh Suhendri, D., Fitriani, E. F., dan Fithri, N. dengan judul penelitian "Rancangan Sistem Kendali Lampu Led Dan Pengunci Pintu Berbasis Raspberry Pi 3 Dengan Teknik Web Interface Menggunakan Adafruit Io" yang dilakukan pada tahun 2019 lalu, meneliti mengenai perancangan sistem berbasiskan IoT dengan menggunakan Adafruit.io sebagai UI.[15]

9. Penelitian yang berjudul "Implementasi modul wifi NodeMCU Esp8266 untuk smart home" dilakukan oleh Wicaksono, M. F, pada tahun 2017 membahas bidang IoT dengan menggunakan NodeMCU ESP8266 yang kemudian diterapkan pada rumah pintar, berbagai sensor digunakan mulai dari sensor LDR, ultrasonik maupun PIR akan mengirim data ke ESP8266. Tujuan penelitian ini yaitu menciptakan rasa nyaman dan aman bagi pengguna ketika sedang dirumah.[16]

Dari hasil literature review yang dilakukan dengan mengambil paper dengan kemiripan dalam penelitian. Penelitian ini ditujukan untuk berfokus pada bagaimana Prototype pendeteksi kebocoran pipa akan mengirimkan notifikasi kepada user via gmail melalui platform adafruit.io.

\section{A. Metode Observasi}

Metode observasi dilakukan oleh peneliti dengan menerapkan alat langsung pada saluran pipa yang ada dirumah dan membaca tekanan yang dihasilkan dari pengetesan alat ini. Observasi sendiri adalah kegiatan yang dilakukan secara 
ilmiah empiris yang beracuan pada data hasil penelitian, paper penelitian, dan juga melalui pengalaman langsung peneliti di lapangan. Observasi bertujuan untuk mendeskripsikan penelitian.[17]

\section{B. Metode Pengembangan Alat}

Pada penelitian ini dilakukan prototyping untuk menerapkan beserta mempraktekan konsep yang telah dirancang. Serta bertujuan untuk mengembangkan masalah dan solusi yang dapat ditemukan[18] dengan metode ini.

Prototyping sendiri berfungsi untuk menggambarkan alat atau sistem yang akan berjalan nantinya. Dengan dijalankannya sistem ini peneliti dapat melakukan troubleshooting[19] yang kemudian dapat mengambil tindakan evaluasi[20] guna menyempurnakan sistem yang berjalan. Hasil dari evaluasi yang telah dilakukan kemudian akan digunakan sebagai sumber penelitian.

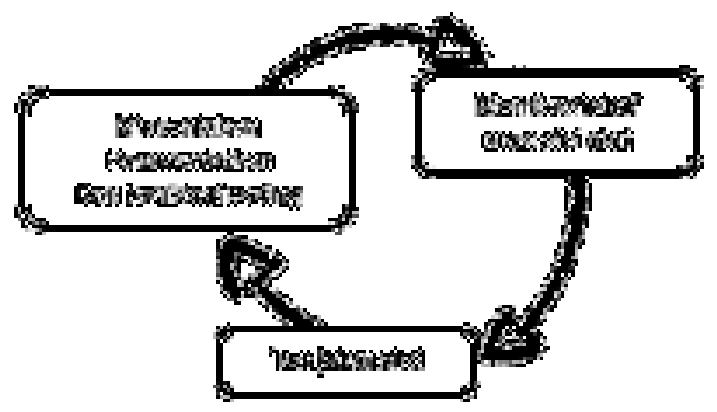

Gambar 1. Prototyping

Untuk mengkoneksikan antara ESP8266 dengan adafruit berikut script yang digunakan peneliti:

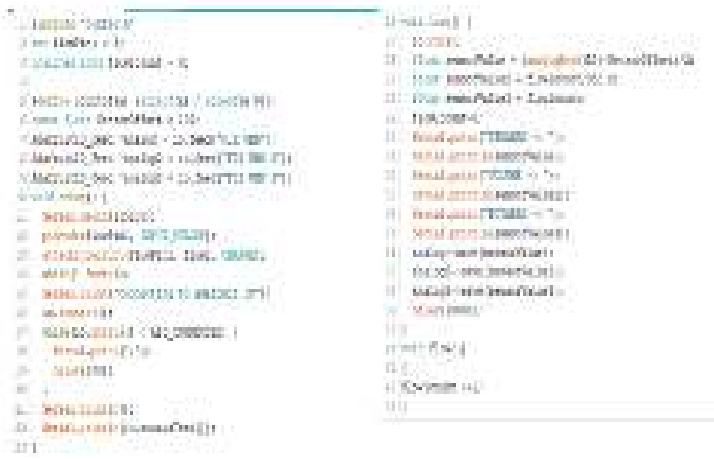

Gambar 2. Script yang digunakan untuk ESP826

\section{HASIL DAN PEMBAHASAN}

Pada penelitian ini digunakan pipa berukuran 1/2" yaitu pipa yang cukup umum digunakan untuk instalasi pipa rumah. Pertama sensor pembaca tekanan yaitu MPX10GP akan dipasangkan pada bagian hulu pipa yang kemudian akan membaca tekanan udara didalam pipa yang telah dihasilkan. Lalu water flow sensor yang berukuran $1 / 2$ " akan dipasang setelah sensor pembaca tekanan yang akan membaca arus air yang pertama masuk pipa untuk kemudian dibaca jumlahnya lalu dikirimkan datanya ke ESP8266.

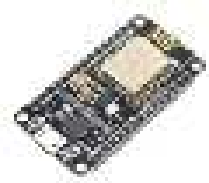

(A) F:03260

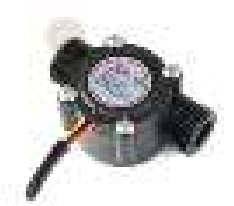

(1) Wus Flowictar:

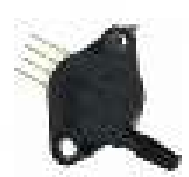

icomatos
Gambar 3. Alat Pencatat arus dan tekanan air

Pipa yang kemudian dibentuk bercabang menggunakan penyambung letter $\mathrm{T}$ berguna untuk menguji aliran air dengan kebocoran ataupun aliran air yang wajar tanpa lubang. Untuk membedakan saluran pipa yang berlubang dan tidak peneliti membuat dua buah valve. Pada hilir alat diletakkan keran sebagai simulasi keran rumah yang digunakan. 
Gambar 4. Alat Prototype Pendeteksi pipa bocor.

Pada pengujiannya alat ini akan membedakan keadaan ketika keran terbuka maupun keran tertutup, apabila keran dalam keadaan tertutup namun ESP8266 tetap memberikan notifikasi melalui email maka ada indikasi kebocoran pipa telah terjadi. Tekanan udara yang berubah di dalam saluran pipa akan terbaca oleh MPX10GP hal ini disebabkan oleh air yang mengalir pada pipa tersebut, apabila saluran pipa dalam keadaan tertutup maka sensor tekanan akan memberikan nilai aman yang telah ditentukan oleh peneliti. Dalam hal ini tekanan setiap pipa akan berbeda tergantung kuatnya tekanan air yang berada di dalamnya, semakin banyak air yang tertahan di dalam saluran maka tekanan udara didalam pipa juga akan ikut naik. Disaat pipa terbuka dan tekanan air menurun menandakan bahwa saluran air sedang dipakai dan apabila tekanan air turun ketika ujung saluran atau keran sedang tertutup makan dapat pipa terindikasi mengalami kebocoran.
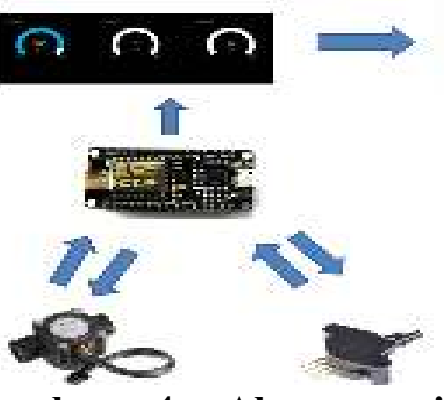

Gambar 4. Alur pengiriman data kepada pengguna.

Berikut merupakan notifikasi yang diberikan via email, notifikasi ini berasal dari adafruit yang menerima data yang dikirimkan NodeMCU ESP8266 dan sensor yang membaca satuan tekanan serta arus. Apabila nilai tekanan dan arus melebihi atau kurang dari nilai yang telah ditentukan maka akan memberikan notifikasi via email. Tidak hanya dari email besaran nilai yang dibaca sensor juga ditampilkan pada dashboard adafruit.

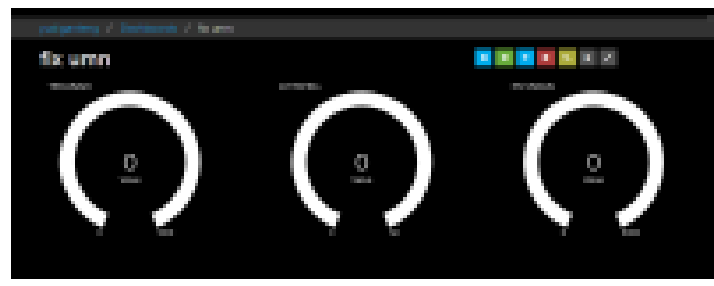

\section{Gambar5.Dashboard adafruit (web based).}

Dari gambar 4 kita dapat melihat ada 3 parameter pengukuran yang pertama ada Tekanan, kedua Liter/10 detik, dan ketiga Putaran yang dihasilkan oleh water flow sensor, namun yang dikirimkan notifikasi via email hanyalah tekanan dan besar debit air yang melewati water flow sensor saja.

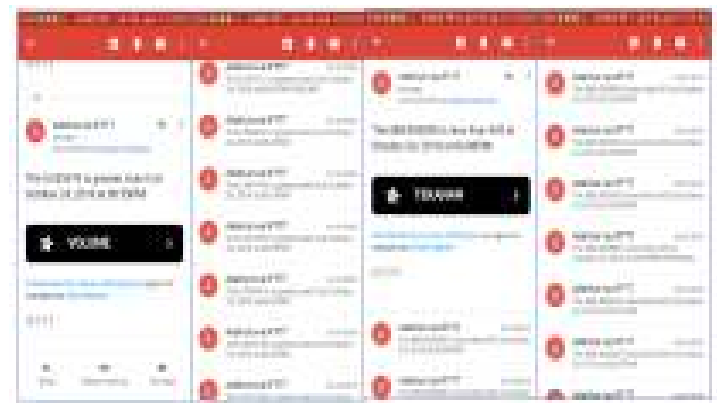

\section{Gambar 6. Notifikasi volume dan} tekanan via email oleh adafruit

Notifikasi yang diberikan ini diatur agar setiap 10 detik sekali update, jadi data yang terekam lebih akurat dan dapat tercatat dengan baik. Hal ini dilakukan karena ESP8266 tidak dapat mengirimkan data dengan timing yang rapat.

\section{SIMPULAN}

Berdasarkan uraian masalah dan analisa pembahasan maka penelitian dapat menyimpulkan Dari hasil penelitian yang telah dilakukan maka dapat disimpulkan bahwa alat pendeteksi kebocoran pipa dapat digunakan untuk mencatat arus air dan tekanan udara yang masuk kedalam pipa namun pengukuran hanya efektif pada 
pipa berukuran $1 / 2$ ". Data yang dicatat dapat memudahkan user untuk mengetahui keadaan tekanan air yang sedang terjadi secara realtime. Sehingga memudahkan pengguna untuk memantau secara langsung dimanapun. Selain itu juga pengguna selalu mendapatkan notifikasi dari alat tersebut.Tekanan pipa setiap saluran pipa akan berbeda tergantung dari kekuatan debit air yang mengalir di dalamnya, sehingga setiap pengguna yang menggunakan alat ini mungkin saja memiliki nilai yang berbeda untuk memicu alat memberikan notifikasi.

\section{SARAN}

Berisi saran-saran yang dapat digunakan untuk penelitian kedepannya, biasanya berisikan usulan metode dan tatacara baru yang dapat digunakan untuk mengembangkan hasil dari penelitian saat ini dan untuk menutup kekurangan yang ada pada penelitian saat ini

\section{DAFTAR PUSTAKA}

[1] Nation, M., Crusto, C., Wandersman, A., Kumpfer, K. L., Seybolt, D., Morrissey-Kane, E., \& Davino, K. (2003). What works in prevention: Principles of effective prevention programs. American psychologist, 58(67), 449.

[2] Rahardja, U., Tejosuwito, N. J., \& Armansyah, F. S. (2017). Perancangan Aplikasi Pen+ Berbasis Mobile untuk Memudahkan Kinerja Dosen pada Perguruan Tinggi. Technomedia Journal, 1(2), 50-60.

[3] Patel, K. K., \& Patel, S. M. (2016). Internet of things-IOT: definition, characteristics, architecture, enabling technologies, application \& future challenges. International journal of engineering science and computing, 6(5).

[4] Thaker, T. (2016, March). ESP8266 based implementation of wireless sensor network with Linux based web-server. In 2016 Symposium on
Colossal Data Analysis and Networking (CDAN) (pp. 1-5). IEEE.

[5] Ramyaa, A. S., \& Rao, K. A. M. E. S. W. A. R. A. (2016). Design and Development of Automatic Water Flow Meter. International Journal of Advanced Technology and Innovative Research, 8(4), 0732-0735.

[6] Rani, K. R., Shabana, N., Tanmayee, P., Loganathan, S., \& Velmathi, G. (2017, March). Smart drip infusion monitoring system for instant alert-through nRF24L01. In 2017 International Conference on Nextgen Electronic Technologies: Silicon to Software (ICNETS2) (pp. 452-455). IEEE.

[7] Clark, J., Falkner, W., Ratkos, R., Kuruvadi, S. B., Bruce, D., Zummo, W., \& Yelamarthi, K. (2019).Development and Implementation of Real-Time Wireless Sensor Networks for Data Literacy Education.

[8] Hariyanto, D., Pauzi, G. A., \& Supriyanto, A. (2017). Deteksi Letak Kebocoran Pipa Berdasarkan Analisis Debit Air Menggunakan Teknologi Sensor Flowmeter Berbasis TCP/IP. Jurnal Teori dan Aplikasi Fisika, 5(1), 25-30.

[9] [9] SHOLACHUDDIN AL AYUB, M. U. C. H. A. M. M. A. D. (2015). Perancangan dan Penerapan Aparatus Pengukuran Debit Air dengan Menggunakan Venturimeter dan Water Flow Sensor. Inovasi Fisika Indonesia, 4(2).

[10] Jenkins, James, and William Vestal. "Water delivery system with water flow sensor for a refrigerator." U.S. Patent Application No. 11/072,430.

[11] Sasmoko, D., \& Wicaksono, Y. A. (2017). Implementasi Penerapan Internet Of Things (Iot) Pada Monitoring Infus Menggunakan Esp8266 Dan Web Untuk Berbagi Data. Jurnal Ilmiah Informatika, 2(1), 90-98. 
[12] Ulumuddin, U., Sudrajat, M., Rachmildha, T. D., Ismail, N., \& Hamidi, E. A. Z. (2018, January). Prototipe Sistem Monitoring Air Pada Tangki Berbasis Internet of Things Menggunakan NodeMCU Esp8266 Dan Sensor Ultrasonik. In Prosiding-Seminar Nasional Teknik Elektro UIN Sunan Gunung Djati Bandung (pp. 100-105).

[13] Kodali, R. K., \& Mahesh, K. S. (2016, December). A low cost implementation of MQTT using ESP8266. In 2016 2nd International Conference on Contemporary Computing and Informatics (IC3I) (pp. 404-408). IEEE.

[14] Prihtiadi, H., Azwar, A., \& Djamal, M. (2016, March). A simple method to determine leakage location in water distribution based on pressure profiles. In AIP Conference Proceedings (Vol. 1719, No. 1, p. 030045). AIP Publishing LLC.

[15] Suhendri, D., Fitriani, E. F., \& Fithri, N. (2019, August). Rancangan Sistem Kendali Lampu Led Dan Pengunci Pintu Berbasis Raspberry Pi 3 Dengan Teknik Web Interface Menggunakan Adafruit Io. In Bina Darma Conference on Engineering Science (BDCES) (Vol. 1, No. 1, pp. 89-97).

[16] Wicaksono, M. F. (2017). Implementasi modul wifi NodeMCU Esp8266 untuk smart home. Komputika: Jurnal Sistem Komputer, 6(1).

[17] Hasanah, H. (2017). Teknik-teknik observasi (sebuah alternatif metode pengumpulan data kualitatif ilmuilmu sosial). At-Taqaddum, 8(1), 21-46.

[18] Wan, J., Tang, S., Shu, Z., Li, D., Wang, S., Imran, M., \& Vasilakos, A. V. (2016). Software-defined industrial internet of things in the context of industry 4.0. IEEE Sensors Journal, 16(20), 73737380 .

[19] Golender, V., Moshe, I. B., \& Wygodny, S. (2018). U.S. Patent No.
10,073,760. Washington, DC: U.S. Patent and Trademark Office.

[20] Mertens, D. M., \& Wilson, A. T. (2018). Program evaluation theory and practice. Guilford Publications. 